Article

\title{
Condensed Phase Guerbet Reactions of Ethanol/Isoamyl Alcohol Mixtures
}

\author{
Iman Nezam ${ }^{1,2, * \mathbb{D}}$, Lars Peereboom ${ }^{2}$ and Dennis J. Miller ${ }^{2}$ \\ 1 School of Chemical and Biomolecular Engineering, Georgia Institute of Technology, Atlanta, GA 30318, USA \\ 2 Chemical Engineering and Materials Science Department, Michigan State University, East Lansing, MI 48824, \\ USA; peereboo@egr.msu.edu (L.P.); millerd@egr.msu.edu (D.J.M.) \\ * Correspondence: inezam3@gatech.edu
}

Received: 13 October 2020; Accepted: 12 November 2020; Published: 16 November 2020

\begin{abstract}
The self-condensation and cross-condensation reactions of ethanol and isoamyl alcohol are examined to better understand the potential routes to value-added byproducts from fuel ethanol production. Reactions have been carried out in both batch autoclave and continuous condensed-phase reactors using a lanthanum-promoted, alumina-supported nickel catalyst at near-critical condensed phase conditions. Analysis of multiple candidate kinetic models led to a Langmuir-Hinshelwood rate expression that is first-order in alcohol with water as the strongly adsorbed species. This model provides the best fit of data from both batch and continuous reactor experiments. Activation energies for primary condensation reactions increase as carbon chain lengths increase. Selectivities to higher alcohols of $94 \%$ and $87 \%$ for ethanol and isoamyl alcohol, respectively, were observed at different operating conditions.
\end{abstract}

Keywords: Guerbet reaction; 3-methyl-1-butanol; kinetic modeling; mechanism; aldol condensation; Langmuir-Hinshelwood

\section{Introduction}

The predominant route for the conversion of hexose sugars (sucrose, glucose, maltose, etc.) to ethanol (EtOH) with yeast of the Saccharomyces family is the Embden Meyerhof pathway [1,2]. In this pathway, the main product ( $\sim 99 \%)$ is EtOH, with the byproducts formed typically referred to as "fusel" oils or alcohols [3,4]. Fusel alcohols consist primarily of isoamyl alcohol (IAOH) (3-methyl-1-butanol) along with $n$-propanol, isobutanol, and optically active amyl alcohol [5]. Whether formed as byproducts of EtOH fermentation [6] or from fermentation-derived amino acids [7], these compounds have essential applications as aroma and flavoring agents in the food and beverage industry [3,8-11]. For instance, isoamyl alcohol is used to produce isoamyl acetate, widely used in the food industry for its banana flavor [12,13]. Further, mixtures of fusel alcohols can be used as solvents or cleaners, and as reagents with various organic acids to make mixed esters that have desirable properties as solvents or as fuel additives [14-16]. But presently, the most common end use of fusel alcohols involves blending with purified $\mathrm{EtOH}$ as fuel for internal combustion engines, where their high energy density and compatibility with hydrocarbons make them attractive additives [12,17-19].

Fusel alcohols contain at least one hydrogen atom on the $\beta$-position of their carbon backbones, and so can participate in Guerbet condensation reactions, in which higher alcohols are formed via one of several postulated condensation mechanisms. Because they are produced along with EtOH and require substantial processing to be recovered in pure form, the opportunity exists to efficiently produce additional higher alcohols via reaction of partially purified fusel alcohols with $\mathrm{EtOH}$ and with each other. With current U.S. EtOH production at approximately 15 billion gallons annually and fusel oils constituting $0.3 \mathrm{wt} \%$ to $0.7 \mathrm{wt} \%(\sim 200 \mathrm{million} \mathrm{kg} / \mathrm{y})$ of total alcohols produced, the 
potential exists to produce fusel oil-based chemicals priced at least an order of magnitude higher than ethanol. This impact would enhance profitability of existing EtOH production, could help facilitate more economical cellulosic-based EtOH production, and would contribute to reducing the selling price of other chemicals derived from $\mathrm{EtOH}$ [20-22].

Despite the comprehensive analysis of the Guerbet condensation of various alcohols via process, catalytic, thermodynamic, and mechanistic aspects [23-28], Guerbet reactions of fusel alcohols have been the subject of only a few studies. Matsu-ura et al. studied the conversion of fusel alcohols over a homogeneous Ir-based catalyst at $120^{\circ} \mathrm{C}$ and atmospheric pressure and obtained yields of as high as $98 \%$ for the self-coupling of $C_{5}$ and $C_{6}$ alcohols, and $86 \%$ for the self-coupling of $C_{12}$ alcohol [29]. They also studied isoamyl alcohol as the reagent and were able to achieve $50 \%$ yield of $C_{10}$ alcohol at the same reaction conditions. Later, Busch et al. confirmed the feasibility of the synthesis of branched $\mathrm{C}_{10}$ alcohols through the Guerbet reaction of isoamyl alcohols at $180^{\circ} \mathrm{C}$ and elevated pressure ranges (1.4-4.6 bar) using a Pd/C-based homogeneous catalyst [30]. Unfortunately, no analytical data were reported.

To date, no studies have been reported for Guerbet condensation reactions of fusel oil components with $\mathrm{EtOH}$. We report here the reaction of isoamyl alcohol (IAOH), the primary constituent of fusel alcohols, with EtOH and with itself at condensed-phase conditions over supported nickel catalyst. Both batch reactions with different initial compositions and continuous, fixed bed reactions at different temperatures and reactor space velocities have been carried out. Higher alcohol yields and selectivities have been determined, and a kinetic model is developed to ascertain the relative rates of condensation of different alcohol species.

\section{Materials and Methods}

\subsection{Materials and Catalyst Preparation}

Isoamyl alcohol (IAOH, >98\%, Sigma-Aldrich, St. Louis, MO, USA) was mixed with anhydrous ethanol (EtOH, 200 proof, Koptec, Montgomery, PA, USA) in the desired ratio as the feed for experiments. The catalyst used for both batch and continuous experiments is $8.0 \mathrm{wt} \% \mathrm{Ni} / 9.0 \mathrm{wt} \% \mathrm{La}_{2} \mathrm{O}_{3} / \gamma-\mathrm{Al}_{2} \mathrm{O}_{3}$, the same catalyst used in previous studies [22,31]. For the preparation of this catalyst via incipient wetness [31], $\mathrm{Ni}\left(\mathrm{NO}_{3}\right)_{2} \cdot 6 \mathrm{H}_{2} \mathrm{O}(99.999 \%$, Aldrich, St. Louis, $\mathrm{MO}, \mathrm{USA})$ and $\mathrm{La}\left(\mathrm{NO}_{3}\right)_{3} \cdot 6 \mathrm{H}_{2} \mathrm{O}(>99 \%$, Fluka, Charlotte, NC, USA) were used as catalyst precursors, and spherical $1.6 \mathrm{~mm}$ diameter $\gamma-\mathrm{Al}_{2} \mathrm{O}_{3}$ (Strem Chemical, Newburyport, MA, USA) was used as the catalyst support.

\subsection{Reactor Systems}

\subsubsection{Batch Reactor Experiments}

Batch reactions were performed in a $300 \mathrm{~mL}$ Parr reactor (Model 4842, Parr Instruments, Chicago, IL, USA). The Parr reactor was equipped with an Omega 1/8" stainless steel Type J thermocouple to measure reaction temperature within $\pm 1^{\circ} \mathrm{C}$. Calibrations for achieving this accuracy were conducted in previous work [32,33]. Reaction pressure was measured using an electronic pressure transducer (maximum pressure $200 \mathrm{~atm}$ ) that was calibrated against a $100 \mathrm{~atm}$ mechanical gauge with increments of $0.7 \mathrm{~atm}$. The mechanical stirrer was set at $1000 \mathrm{rpm}$ during the reaction.

After adding alcohols and catalyst, the reactor was sealed and purged with nitrogen at $1.0 \mathrm{~atm}$ overpressure. The reactions were carried out at autogenous pressure. An initial liquid sample was taken after nitrogen purging and before heating to the reaction temperature to verify initial composition. At the end of the reaction, the reactor was cooled and then depressurized. The total quantity of liquid products formed was taken as the sum of liquid sample masses collected and residual liquid in the reactor following depressurization. A sample of this residual liquid was weighed and then analyzed by gas chromatography as described below. The total quantity of gaseous products formed during reaction was determined by measuring the change in cooled reactor mass over the course of 
depressurization and collecting the gas in a sample bag. By determining the volume of gas collected via water displacement, the average molecular weight of the gas product was determined.

\subsubsection{Continuous Reactor Experiments}

A $1.91 \mathrm{~cm}$ external diameter $(1.57 \mathrm{~cm}$ ID) by $76 \mathrm{~cm}$ length jacketed 316 Stainless Steel up-flow packed bed reactor was used for continuous experiments. Approximately $30 \mathrm{~g}$ of catalyst were placed in the reactor. The temperature profile during reaction was measured with a Type $\mathrm{K}$ thermocouple inside a $3 \mathrm{~mm}$ OD internal thermowell located on the center axis of the reactor. The reactor temperature was controlled by circulating silicon oil through the jacket using a Julabo (Model SE-6) heating circulator. A Tescom (Model 26-1764-24) back-pressure regulator was used to control the reactor pressure at 100 bar and reduce the effluent pressure to near atmospheric. To preheat the feed mixture to the reactor temperature, silicon carbide ( $\mathrm{SiC}, 20-50 \mathrm{mesh}$ ) was placed upstream of the catalyst bed. Stainless steel rod fillers were also used before and after the reaction zone to reduce dead space in the reactor.

A feed composition of $79 \mathrm{~mol} \% \mathrm{EtOH}$ and $21 \mathrm{~mol} \% \mathrm{IAOH}$ was used in continuous flow experiments. Reactor temperature was varied from $210{ }^{\circ} \mathrm{C}$ to $250{ }^{\circ} \mathrm{C}$, and the liquid feed flow rate was varied from $0.5 \mathrm{~mL} / \mathrm{min}$ to $1.3 \mathrm{~mL} / \mathrm{min}$, corresponding to a weight hourly space velocity (WHSV) of $0.8 \mathrm{~h}^{-1}$ to $2.1 \mathrm{~h}^{-1}$ or a superficial residence time $(\tau)$ of 0.96 to $0.25 \mathrm{~m}^{3}$ reactor $/\left(\mathrm{m}^{3}\right.$ feed/h), respectively. Once steady state operation of the reactor was achieved, condensable liquid products were collected in an ice/water trap over a period of time ranging from 30 to $90 \mathrm{~min}$ depending on the feed rate. The liquid product collected was analyzed using gas chromatography as discussed in the following section. The gaseous products were collected in a gas bag located downstream of the ice/water trap and quantified by the measurement of effluent gas rate at several time points during the product collection period.

\subsection{Analytical Methods}

The analytical methods and instruments used in this study are the same as those described in previous studies [22,31-33]. Liquid product samples were diluted 10-fold in acetonitrile and analyzed using a Varian 450 gas chromatograph (GC) with a flame ionization detector. A $30 \mathrm{~m}$ SolGel-Wax column ( $0.53 \mathrm{~mm}$ ID, $1 \mathrm{~mm}$ film thickness) was used with the following temperature program: initial temperature $37^{\circ} \mathrm{C}$ for $4 \mathrm{~min}$; ramp at $10^{\circ} \mathrm{C} / \mathrm{min}$ to $90^{\circ} \mathrm{C}$, and hold at $90^{\circ} \mathrm{C}$ for $3 \mathrm{~min}$; ramp at $10^{\circ} \mathrm{C} / \mathrm{min}$ to $150{ }^{\circ} \mathrm{C}$; ramp at $30{ }^{\circ} \mathrm{C} / \mathrm{min}$ to $230{ }^{\circ} \mathrm{C}$ and hold for $2 \mathrm{~min}$. Butyl hexanoate $1 \%$ solution was used as an internal standard in liquid product GC analyses. Multi-point calibration curves were used to determine the response factor of each known product. Unidentified liquid product peaks were quantified for carbon recovery calculations by using an average molecular weight and response factor based on values from adjacent known peaks in the chromatogram.

The number of moles of gas formed in reaction was determined volumetrically as described above. From the average molecular weight of gas byproducts, which ranged from 18 to $22 \mathrm{~g} / \mathrm{mol}$ in all experiments, it was assumed that on average one mole of carbon was present in each mole of gas formed. Selected gas samples were analyzed by gas chromatography, as presented in previous works [22,31-34], to support this assumption. The typical composition of gas byproducts is shown in Figure S1a of Supporting Information.

An in-house Excel spreadsheet was used to convert the species concentrations from GC analyses to EtOH and IAOH conversion, selectivity to each higher alcohol formed from a particular feed alcohol (mol feed alcohol to product $/ \mathrm{mol}$ feed alcohol converted), overall selectivity to liquid byproducts (mol C in liquid byproducts/mol C in EtOH + IA converted), overall selectivity to gas byproducts (mol C in gas byproducts/mol C in EtOH + IA converted), and overall carbon recovery (mol C in reactor effluent/mol $\mathrm{C}$ in feed alcohols). Overall carbon recovery is the carbon balance that reflects uncertainty in experimental methods and analysis, and therefore exceeds $100 \%$ in some cases. Selectivity to liquid byproducts was normalized to make total product selectivity sum to $100 \%$ in cases where total carbon recovery exceeded $100 \%$. Selectivity to liquid byproducts and gas byproducts is presented on a carbon 
basis based on both feed alcohols taken together, as it was not possible to distinguish between the two alcohols as the source of some liquid and gas byproducts in mixed alcohol feed experiments.

To further characterize the product composition, Karl Fischer titration was carried out in triplicate to determine water content of each sample. This value was used as a check of the overall molar balances for the reaction; the quantity of water formed was usually $25-30 \%$ greater than that predicted by the extent of alcohol condensations. The excess water formation arises from side reactions to form gas and liquid byproducts.

\section{Results}

\subsection{Experimental Results}

Guerbet reactions with two alcohols lead to a significantly wider variety of product species than for a single alcohol. The key higher alcohol products of the mixed $\mathrm{IAOH}$ and $\mathrm{EtOH}$ experiments are shown on the right side of Figure 1; the alcohols responsible for forming the products are shown on the left side of Figure 1.

\section{Condensing Alcohols}<smiles>CC[OH+][CH]CO</smiles><smiles>CCO[14CH2]CCCO</smiles><smiles>CC[OH+]CCCCCCO</smiles><smiles>CCO[OH+]C(C)CCO</smiles><smiles>CCCCO[C+]C(C)CCO</smiles><smiles>CC(C)CCO</smiles>

\section{Product Alcohols}

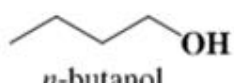<smiles>CCCCCCO</smiles>

1-hexanol<smiles>CCC(CC)CO</smiles>

2-ethyl-1-butanol<smiles>CCCCCCCCO</smiles><smiles>CCCCC(CC)CO</smiles>

2-ethyl-1-hexanol<smiles>CC(C)CCCCO</smiles><smiles>CCC(CO)C(C)C</smiles>

2-ethyl-3-methyl-1-butanol<smiles>CCC(CO)CCC(C)C</smiles><smiles>CCCCC(CO)C(C)C</smiles>

2-isopropyl-1-hexanol<smiles>CC(C)CCC(CO)C(C)C</smiles>

2-isopropyl-5-methyl-1-hexanol

Figure 1. Primary products observed from reaction of $\mathrm{EtOH}$ and $\mathrm{IAOH}$ mixtures. 
In addition to desired higher alcohol products, liquid byproducts are formed at the reaction conditions examined. The typical composition of these liquid byproducts for experiments with pure $\mathrm{EtOH}$ and $\mathrm{IAOH}$ is given in Figure S1b,c of the Supporting Information. Additional peaks that likely represent liquid byproducts of reactions between $\mathrm{EtOH}$ and $\mathrm{IAOH}$ or their reaction intermediates were observed in chromatograms of liquid samples. No attempt was made to identify these byproducts of cross alcohol reactions, although they were included in the overall carbon balance for experiments by estimating the carbon number of each product based on its location in the chromatogram.

\subsubsection{Batch Experiments}

Experiments were conducted at $230{ }^{\circ} \mathrm{C}$ with $4.85 \mathrm{~g}$ of catalyst and $120 \mathrm{~g}$ of feed alcohols of composition varying from $100 \% \mathrm{EtOH}$ to $100 \% \mathrm{IAOH}$. Reactions B2-B6 were run for $24 \mathrm{~h}$, and Reaction B7 was run for $51 \mathrm{~h}$. Results obtained from batch reaction studies are summarized in Table 1.

Table 1. Results of condensed phase batch reactor experiments with EtOH-IAOH mixtures. Conditions:

$230{ }^{\circ} \mathrm{C} ; 4.85 \mathrm{~g} 8.0 \mathrm{wt} \% \mathrm{Ni} / 9.0 \mathrm{wt} \% \mathrm{La}_{2} \mathrm{O}_{3} / \gamma-\mathrm{Al}_{2} \mathrm{O}_{3}$ catalyst; autogenous pressure.

\begin{tabular}{|c|c|c|c|c|c|c|c|c|c|c|c|c|c|c|}
\hline \multirow{3}{*}{ Exp. ${ }^{a}$} & \multirow{3}{*}{$\begin{array}{l}\text { Initial } \\
\text { Molar } \\
\text { Ratio } \\
\text { EtOH/ } \\
\text { IAOH }\end{array}$} & \multicolumn{2}{|c|}{$\begin{array}{c}\text { Conversion } \\
(\%)\end{array}$} & \multicolumn{8}{|c|}{ Selectivity to Higher Alcohols (\%) } & \multirow{3}{*}{$\begin{array}{c}\text { Selectivity } \\
\text { to Liquid } \\
\text { Byproducts } \\
(\%)\end{array}$} & \multirow{3}{*}{$\begin{array}{c}\text { Selectivity } \\
\text { to Gas } \\
\text { Byproducts } \\
(\%)\end{array}$} & \multirow{3}{*}{$\begin{array}{c}\text { Overall } \\
\text { Carbon } \\
\text { Recovery } \\
(\%)\end{array}$} \\
\hline & & \multirow{2}{*}{ EtOH } & \multirow{2}{*}{ IAOH } & \multicolumn{3}{|c|}{ EtOH Products } & \multicolumn{4}{|c|}{ Cross Products } & \multirow{2}{*}{$\begin{array}{c}\text { IAOH } \\
\text { Prod. }\end{array}$} & & & \\
\hline & & & & $\mathrm{C}_{4}$ & $\mathrm{C}_{6}$ & $\mathrm{C}_{8}$ & $\mathrm{C}_{7}$ & $\mathrm{C}_{9}$ & $\mathrm{C}_{7}$ & $\mathrm{C}_{9}$ & & & & \\
\hline B2 & $100 / 0$ & 21.1 & - & 67.5 & 22.0 & 5.0 & - & - & - & - & - & 3.4 & 2.1 & 105.3 \\
\hline B4 & $20 / 80$ & 43.3 & 9.7 & 25.5 & 3.2 & 8.6 & 39.5 & 2.9 & 43.8 & 2.9 & 3.2 & 39.2 & 3.5 & 102.9 \\
\hline B6 & $0 / 100$ & - & 11.1 & - & - & - & - & - & - & - & 4.8 & 86.9 & 8.3 & 97.3 \\
\hline B7 & $79 / 21$ & 40.5 & 14.6 & 47.9 & 15.9 & 3.6 & 5.9 & 0.1 & 62.9 & 8.7 & 0.6 & 25.7 & 1.2 & 101.0 \\
\hline
\end{tabular}

\subsubsection{Continuous Experiments}

Condensed-phase continuous reactions were carried out at $100 \mathrm{bar}$ over $8 \mathrm{wt} \% \mathrm{Ni} / 9 \mathrm{wt} \%$ $\mathrm{La}_{2} \mathrm{O}_{3} / \mathrm{Al}_{2} \mathrm{O}_{3}$ catalyst with a feed composition of $79 \mathrm{~mol} \% \mathrm{EtOH}$ and $21 \mathrm{~mol} \% \mathrm{IAOH}$. Results of continuous flow experiments are given in Table 2. Prior to these experiments, control studied were performed with the same feed composition and catalyst at ambient conditions and without any catalyst at reaction conditions to ensure that the system does not contain any leaks and the reactor material does not provide any reactivity to the feed material.

Table 2. Results of condensed-phase continuous reactor experiments. Conditions: 79/21 molar feed ratio of $\mathrm{EtOH} / \mathrm{IAOH} ; 29.9 \mathrm{~g}$ of $8.0 \mathrm{wt} \% \mathrm{Ni} / 9.0 \mathrm{wt} \% \mathrm{La}_{2} \mathrm{O}_{3} / \gamma-\mathrm{Al}_{2} \mathrm{O}_{3}$ catalyst; 100 bar pressure.

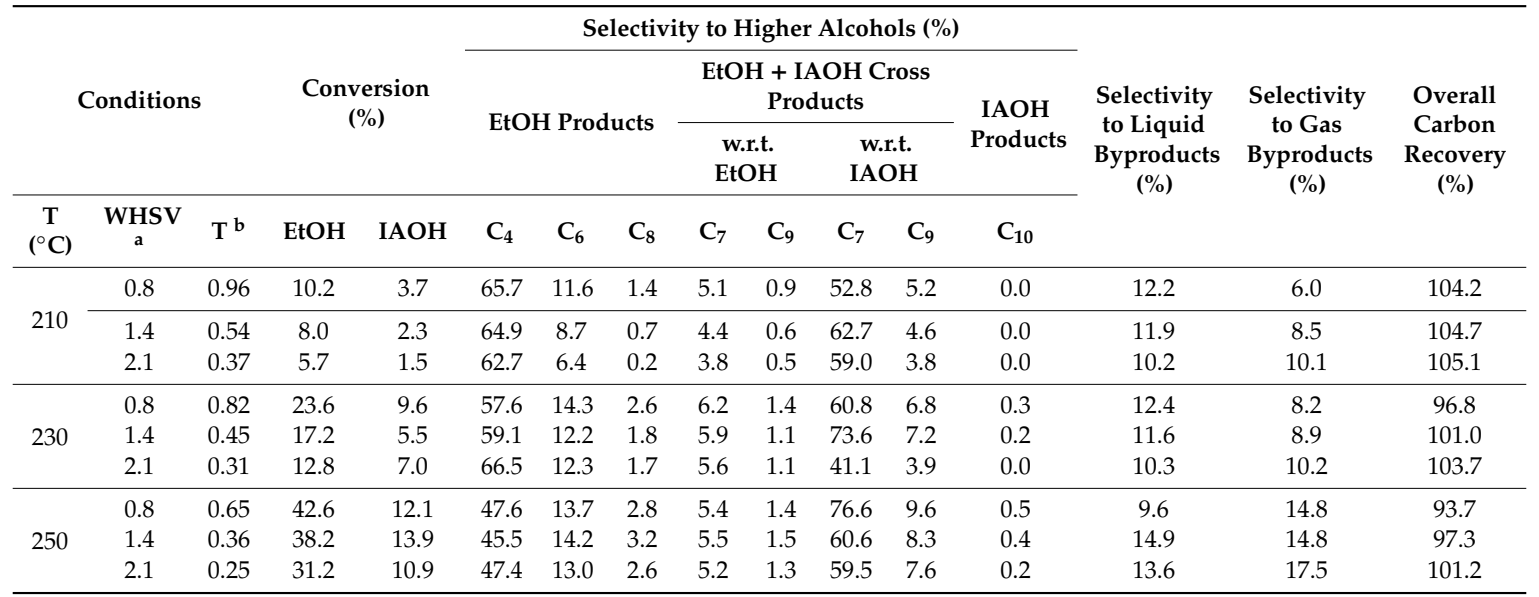

a WHSV = weight hourly space velocity $(\mathrm{kg}$ feed alcohols $/ \mathrm{kg}$ cat $/ \mathrm{h}) ;{ }^{\mathrm{b}} \tau=$ superficial residence time $\left(\mathrm{m}^{3}\right.$ reactor $/\left(\mathrm{m}^{3}\right.$ feed $\left.\left./ \mathrm{h}\right)\right)$. 
Results in Tables 1 and 2 show EtOH selectivity toward higher alcohols ranging from 70-85\% through both self-condensation and cross-condensation reaction with IAOH. The conversion rate of $\mathrm{IAOH}$ is lower than that of $\mathrm{EtOH}$; very little $\mathrm{C}_{10}$ product, the direct condensation product of $\mathrm{IAOH}$, is formed. Nearly all IAOH reaction to higher alcohols takes place with $\mathrm{EtOH}$ to form the $\mathrm{C}_{7}$ alcohol, even at lower initial EtOH/IAOH molar ratios (Exp. B4). The composition of IAOH liquid byproducts, shown in Figure S1c, indicates that formation of the initial aldehyde intermediate (3-methyl-butanal) of $\mathrm{IAOH}$ is significant, but the subsequent condensation of the intermediate to the $\mathrm{C}_{10}$ product alcohol is slow. Steric hindrance resulting from the longer carbon chain length likely plays a role in condensation to form the $\mathrm{C}_{10}$ product. The conversion rate of $\mathrm{IAOH}$ to liquid and gas byproducts, based on outlet concentrations of species in Figure S1, is similar to that of EtOH.

\subsection{Kinetic Model Development}

A kinetic model has been developed, based on prior studies of condensed-phase ethanol conversion [22,31-33], to characterize reaction rates in the EtOH/IAOH reaction system. The following Guerbet (condensation) reactions are considered:

$$
\begin{aligned}
& \text { EtOH self- condensation : } \mathrm{C}_{2} \mathrm{H}_{5} \mathrm{OH}+\mathrm{C}_{2} \mathrm{H}_{5} \mathrm{OH} \stackrel{\mathrm{k}_{1}}{\rightarrow} \mathrm{C}_{4} \mathrm{H}_{9} \mathrm{OH}+\mathrm{H}_{2} \mathrm{O} \\
& \text { EtOH - IAOH condensation: } \mathrm{C}_{2} \mathrm{H}_{5} \mathrm{OH}+\mathrm{C}_{5} \mathrm{H}_{11} \mathrm{OH} \stackrel{\mathrm{k}_{2}}{\rightarrow} \mathrm{C}_{7} \mathrm{H}_{15} \mathrm{OH}+\mathrm{H}_{2} \mathrm{O} \\
& \text { IAOH self- condensation: } \mathrm{C}_{5} \mathrm{H}_{11} \mathrm{OH}+\mathrm{C}_{5} \mathrm{H}_{11} \mathrm{OH} \stackrel{\mathrm{k}_{3}}{\rightarrow} \mathrm{C}_{10} \mathrm{H}_{21} \mathrm{OH}+\mathrm{H}_{2} \mathrm{O} \\
& \text { EtOH }- \text { BuOH condensation: } \mathrm{C}_{2} \mathrm{H}_{5} \mathrm{OH}+\mathrm{C}_{4} \mathrm{H}_{9} \mathrm{OH} \stackrel{\mathrm{k}_{4}}{\rightarrow} \mathrm{C}_{6} \mathrm{H}_{13} \mathrm{OH}+\mathrm{H}_{2} \mathrm{O}
\end{aligned}
$$

In addition to these Guerbet reactions, two additional reactions (assumed to be first-order in alcohols) are required to account for conversion of $\mathrm{EtOH}$ and $\mathrm{IAOH}$ to gas and liquid byproducts. Including these reactions is necessary to maintain the correct feed alcohol concentration profile in the reactor.

$$
\begin{gathered}
\text { EtOH side reactions : } \mathrm{C}_{2} \mathrm{H}_{5} \mathrm{OH} \stackrel{\mathrm{k}_{5}}{\rightarrow} \mathrm{E}_{\text {other }} \\
\text { IAOH side reactions : } \mathrm{C}_{5} \mathrm{H}_{11} \mathrm{OH} \stackrel{\mathrm{k}_{6}}{\rightarrow} \mathrm{IA}_{\text {other }}
\end{gathered}
$$

Since the selectivities to $C_{8}$ and $C_{9}$ alcohols formed in continuous reactor experiments were low, the formation of $C_{8}$ product alcohols is combined with $C_{6}$ alcohol formation, and the formation of $C_{9}$ product alcohols is combined with $\mathrm{C}_{7}$ alcohol formation in the kinetic model. This is warranted because $\mathrm{C}_{8}$ and $\mathrm{C}_{9}$ alcohols are formed via further reaction of $\mathrm{C}_{6}$ and $\mathrm{C}_{7}$ alcohols with $\mathrm{EtOH}$, respectively, as opposed to reactions of higher alcohols $\left(\mathrm{C}_{4}+\mathrm{C}_{4}\right.$ to $\mathrm{C}_{8}$, for example). EtOH is both more reactive than higher alcohols and $\mathrm{EtOH}$ is present in much higher concentration than other alcohols. The low selectivities to $\mathrm{C}_{8}$ and $\mathrm{C}_{9}$ products, and associated uncertainty with their low concentrations in the product mix, does not warrant the additional complexity of another rate expression and rate constant for each in the kinetic model.

Initially, kinetic rate expressions for R1-R4 were assumed to be second-order in alcohols. However, this simple second-order model did not provide a satisfactory fit of either batch or continuous reaction data. Analysis of the "indirect" mechanism [27,31,35-38] of EtOH condensation to $\mathrm{BuOH}$ (see Supplementary Information) [31], where $\mathrm{EtOH}$ dehydrogenates to acetaldehyde $(A A)$, $A A$ undergoes aldol condensation to crotonaldehyde $(C A)$, and $C A$ hydrogenates to $\mathrm{BuOH}$, shows that ethanol condensation rate is first-order in $\mathrm{EtOH}$ if (1) local $\mathrm{H}_{2}$ concentration is assumed to be equal to $A A$ concentration, and (2) either EtOH dehydrogenation or $A A$ condensation are rate-limiting.

Prior work [33] showed that the presence of water $(W)$, present initially or produced in reaction, inhibits the rate of $\mathrm{EtOH}$ condensation to $\mathrm{BuOH}$. Other studies also have shown that the presence of water can limit the extent of dissociative $\mathrm{H}_{2}$ adsorption on $\mathrm{Ni}[39,40]$ and other metal $[41,42]$ surfaces, thus affecting initial alcohol dehydrogenation in the Guerbet reaction system. 
Therefore, a Langmuir-Hinshelwood (L-H) rate expression can be written for EtOH condensation to $\mathrm{BuOH}(\mathrm{R} 1)$ :

$$
r_{1}=\frac{k_{1} C_{E}}{\left(1+K_{W} C_{W}\right)}
$$

A similar rate expression can be written for $\mathrm{IAOH}$ condensation to $\mathrm{C}_{10}$ alcohols, if only IAOH is present.

For reactions involving $\mathrm{EtOH} / \mathrm{IAOH}$ mixtures, generating rate expressions based on rigorous analysis of the indirect mechanism is challenging (see Supplementary Information), because $\mathrm{H}_{2}$ is produced both by $\mathrm{EtOH}$ and $\mathrm{IAOH}$ dehydrogenation. The rates are thus coupled, and the resulting rate expressions are complex. However, because in this study $\mathrm{EtOH}$ is present in larger molar quantities than $\mathrm{IAOH}$, and EtOH reaction rate is faster than that of $\mathrm{IAOH}$, the assumption can be made that $\mathrm{H}_{2}$ forms predominantly from EtOH. With this assumption, the condensation reaction of IAOH (R3), and the cross-condensation reactions of $\mathrm{EtOH}$ with $\mathrm{IAOH}(\mathrm{R} 2)$ and with $\mathrm{BuOH}$ (R4) simplify to be first-order only in $\mathrm{IAOH}$ and $\mathrm{BuOH}$, respectively. Including the $\mathrm{L}-\mathrm{H}$ water adsorption term gives the final form of the rate expression for R2-R6. Details of the model development and the explicit rate expressions for R1-R6 are given in Supplementary Information.

The rate expressions described above have been applied to experimental data to determine the rate constants; the process to fit the kinetic model to data is given in the sections below. To ensure that these rate expressions best fit the experimental data, several alternate kinetic models were evaluated. In addition to the simple second-order rate expression, L-H rate expressions with water adsorption and the numerator second-order in alcohols were examined. Similar L-H rate expressions with EtOH, $\mathrm{IAOH}$, or $\mathrm{BuOH}$ as the dominant adsorbing species were also examined. None of these kinetic models provided as good a fit to experimental data as the model that is first-order in alcohols with water as the dominant adsorbing species.

\subsubsection{Continuous Reactor Modeling}

The experimental data from the continuous reactor were used to determine the values of the rate constants for R1-R6. This was accomplished by writing the differential molar balances for each species in the reaction system (Equations (1)-(8) below) and numerically integrating them (using Euler's method in Microsoft Excel) to determine outlet concentrations from the reactor at each residence time. Reactor feed concentrations were calculated from densities of $\mathrm{EtOH}$ and $\mathrm{IAOH}$ at each reaction temperature and are given in Table S2 of the Supporting Information; the inlet concentrations vary significantly over the temperature range from $210{ }^{\circ} \mathrm{C}$ to $250{ }^{\circ} \mathrm{C}$ because the feed is an expanded liquid at these conditions close to the critical temperatures of each alcohol.

For brevity in the following equations, $\mathrm{EtOH}\left(\mathrm{C}_{2} \mathrm{H}_{5} \mathrm{OH}\right)$ and $\mathrm{IAOH}\left(\mathrm{C}_{5} \mathrm{H}_{11} \mathrm{OH}\right)$ are represented as $\mathrm{E}$ and $\mathrm{IA}, \mathrm{BuOH}\left(n-\mathrm{C}_{4} \mathrm{H}_{9} \mathrm{OH}\right)$ and $\mathrm{C}_{10} \mathrm{H}_{21} \mathrm{OH}$ are represented as the $\mathrm{C}_{4}$ and $\mathrm{C}_{10}$ condensation products of $\mathrm{EtOH}$ and $\mathrm{IAOH}$, respectively. The terms $\mathrm{C}_{6}, \mathrm{C}_{7}, \mathrm{C}_{8}$, and $\mathrm{C}_{9}$ refer to multiple cross-condensation alcohol products with the designated carbon number (Figure 1); identification of the structure of each individual alcohol with these carbon numbers was not attempted. Reaction rates $r_{i}$ in Equations (1)-(8) refer to Reactions 1-6 above.

$$
\begin{gathered}
\frac{1}{\rho_{c a t}} \frac{d C_{E}}{d \tau}=-2 r_{1}-r_{2}-r_{4}-r_{5} \\
\frac{1}{\rho_{c a t}} \frac{d C_{I A}}{d \tau}=-r_{2}-2 r_{3}-r_{6} \\
\frac{1}{\rho_{c a t}} \frac{d C_{C 10}}{d \tau}=r_{3} \\
\frac{1}{\rho_{c a t}} \frac{d C_{C 4}}{d \tau}=r_{1}-r_{4}
\end{gathered}
$$




$$
\begin{gathered}
\frac{1}{\rho_{\text {cat }}} \frac{d C_{C 6}}{d \tau}=r_{4} \\
\frac{1}{\rho_{\text {cat }}} \frac{d C_{C 7}}{d \tau}=r_{2} \\
\frac{1}{\rho_{\text {cat }}} \frac{d C_{\text {Eother }}}{d \tau}=r_{5} \\
\frac{1}{\rho_{\text {cat }}} \frac{d C_{\text {IAother }}}{d \tau}=r_{6}
\end{gathered}
$$

In the above equations, has units of ( $\mathrm{kmol}$ alcohol $/ \mathrm{kg}$ catalyst $/ \mathrm{h}), \rho_{\text {cat }}$ is the catalyst bulk density ( $\mathrm{kg} \mathrm{cat} / \mathrm{m}^{3}$ reactor volume), and $\tau=$ superficial residence time $\left(\mathrm{m}^{3}\right.$ reactor $/\left(\mathrm{m}^{3}\right.$ feed $\left./ \mathrm{h}\right)$ ).

\subsubsection{Rate Constant Determination from Continuous Reactor Data}

Evaluation of the observable modulus $\eta \varphi^{2}$ at the reactor inlet at $250^{\circ} \mathrm{C}$ (Supporting Information) shows that there are, in the worst case, modest intraparticle mass transfer resistances in the reactions studied. Values of the six rate constants and the adsorption equilibrium constant for water $\left(K_{W}\right)$ were adjusted independently at each reaction temperature to minimize the objective function, taken as the sum of the square of differences between experimental and modeled outlet concentrations $\left(\left(C_{i_{E x p}}-C_{i_{M o d}}\right)^{2}\right)$ at each residence time for pertinent species in each reaction.

Rate constants for the reactions of $\mathrm{EtOH}\left(\mathrm{k}_{5}\right)$ and $\mathrm{IAOH}\left(\mathrm{k}_{6}\right)$ to byproducts were determined by setting the quantity of byproducts formed equal to the quantity of each feed alcohol reacted that was not converted to higher alcohol product, thus maintaining the correct feed alcohol concentration profile through the reactor. Depending on the conditions, the fraction of EtOH or IAOH converted to byproducts ranged from $12 \%$ to $33 \%$ in the continuous reactor.

From the optimized rate constant values at each reaction temperature $\left(210{ }^{\circ} \mathrm{C}, 230^{\circ} \mathrm{C}\right.$, and $\left.250{ }^{\circ} \mathrm{C}\right)$, an Arrhenius plot for each rate constant was generated to determine the activation energy and pre-exponential factor. The Arrhenius plots are shown in Figure S2 of the Supporting Information. Values of activation energies and pre-exponential factors for each reaction, along with the value of the rate constant at $230^{\circ} \mathrm{C}$, are given in Table 3 below.

Table 3. Values of activation energy, pre-exponential factor and rate constant for each Reaction $i$ at $230{ }^{\circ} \mathrm{C}$

\begin{tabular}{ccccccccc}
\hline & unit & $\boldsymbol{i}$ & $\mathbf{1}$ & $\mathbf{2}$ & $\mathbf{3}$ & $\mathbf{4}$ & $\mathbf{5}$ & $\mathbf{6}$ \\
\hline $\mathrm{E}_{\mathrm{a}, i}$ & $(\mathrm{~kJ} / \mathrm{mol})$ & 127.7 & 140.2 & 176.0 & 82.53 & 167.2 & 128.0 & $-7.2^{*}$ \\
$\ln \left(\mathrm{k}_{\mathrm{o}, i}\right)$ & $\left(\mathrm{m}^{6} / \mathrm{kg} \mathrm{cat} / \mathrm{kmol} / \mathrm{h}\right)$ & 22.48 & 25.06 & 27.36 & 13.01 & 31.42 & 21.22 & $-0.677^{+}$ \\
$\mathrm{k}_{i}\left(230^{\circ} \mathrm{C}\right)$ & $\left(\mathrm{m}^{6} / \mathrm{kg} \mathrm{cat} / \mathrm{kmol} / \mathrm{h}\right)$ & $3.18 \times 10^{-4}$ & $2.10 \times 10^{-4}$ & $4.00 \times 10^{-7}$ & $1.20 \times 10^{-3}$ & $1.91 \times 10^{-4}$ & $8.45 \times 10^{-5}$ & $2.9^{+}$ \\
\hline
\end{tabular}

${ }^{*}$ Equivalent heat of adsorption of water $(\mathrm{kJ} / \mathrm{mol}),{ }^{+}$units are $\left(\mathrm{m}^{3} / \mathrm{kmol} \mathrm{W}\right)$.

The comparisons of experimental and simulated outlet concentrations of several key species in the EtOH-IAOH reaction system are shown in Figure $2 \mathrm{a}-\mathrm{d}$. The kinetic model simulates the consumption of reactants and formation of products quite well over the temperature and residence time range studied. The complete comparison of experimental and simulated outlet concentrations of every species in every experiment is provided in Table S3 of Supporting Information.

A comparison of the rate constants at $230{ }^{\circ} \mathrm{C}$ in Table 3 for the various condensation reactions shows a decrease in value as alcohol chain lengths increase from $C_{2}-C_{2}\left(k_{1}\right)$ to $C_{2}-C_{5}\left(k_{2}\right)$ to $C_{5}-C_{5}$ $\left(k_{3}\right)$. The activation energy for these three condensation reactions also increases as the chain length increases, in accordance with the expected steric effects associated with the longer carbon backbone of the alcohols. Interestingly, the rate constant $\left(k_{4}\right)$ for $\left(C_{6}+C_{8}\right)$ formation from $C_{2}$ plus $C_{4}$ is larger than that of $\mathrm{C}_{2}-\mathrm{C}_{2}$ condensation, and the activation energy for $\mathrm{R} 4$ is lower. It is possible that the kinetic model does not capture the formation pathway of $\left(\mathrm{C}_{6}+\mathrm{C}_{8}\right)$ alcohols correctly (e.g., perhaps there is a direct route to $\mathrm{C}_{6}$ formation that does not involve $\mathrm{C}_{4}$ explicitly), or that $\mathrm{C}_{4}$ and $\mathrm{C}_{6}$ alcohols, 
once formed, have a locally higher concentration within the catalyst that results in locally higher reaction rates and thus a larger rate constant.
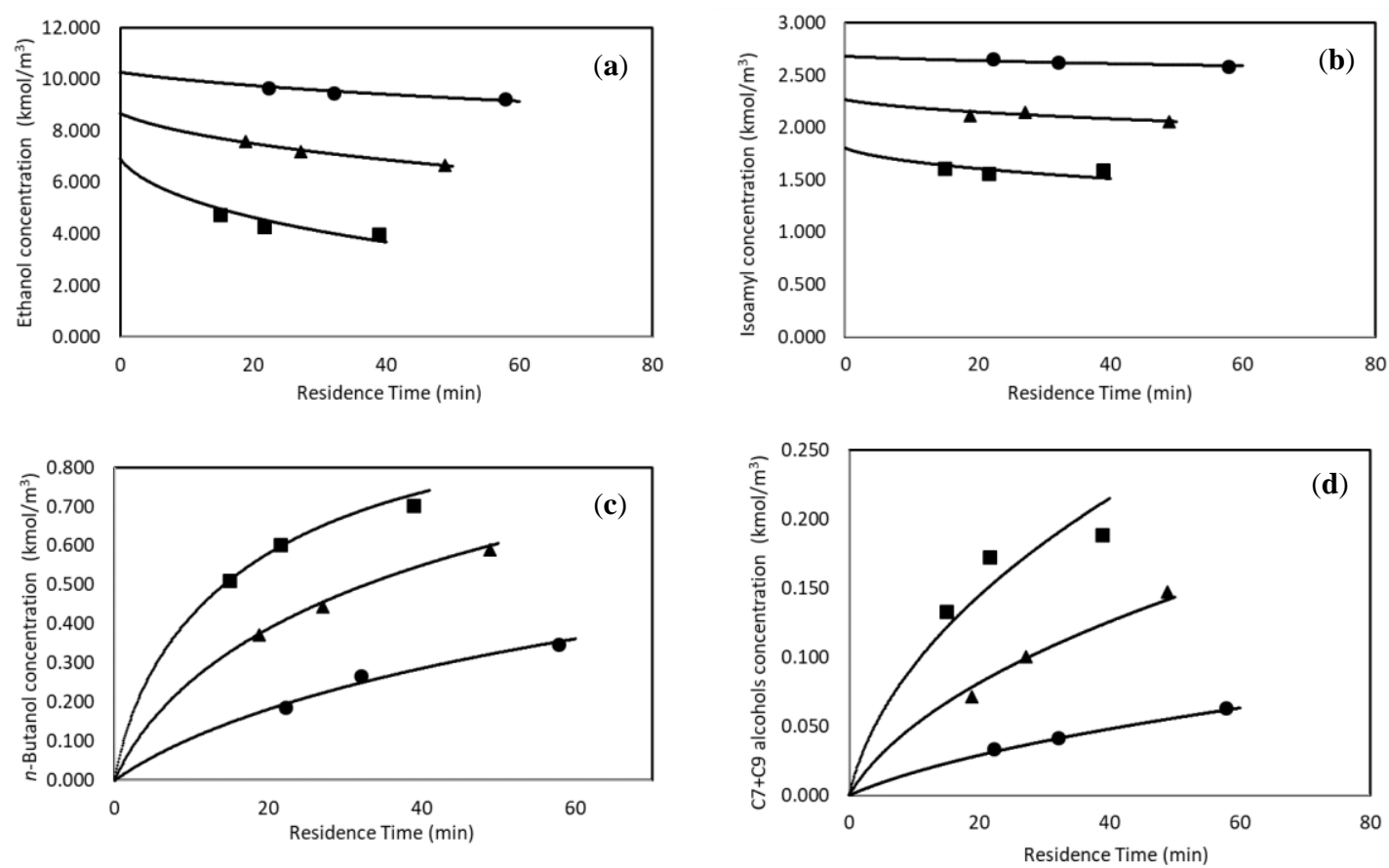

Figure 2. Kinetic model fit to experimental data in continuous flow reactor. Experimental data: $(\bullet)-210{ }^{\circ} \mathrm{C} ;(\boldsymbol{\Delta})-230{ }^{\circ} \mathrm{C} ;(\boldsymbol{\square})-250{ }^{\circ} \mathrm{C}$. Solid lines are simulated values at each temperature. (a) EtOH (E); (b) IAOH alcohol (IA); (c) n-butanol $\left(\mathrm{C}_{4}\right)$; (d) $\mathrm{C}_{7}+\mathrm{C}_{9}$ alcohols.

\subsubsection{Comparison of Batch Experimental Data with Kinetic Model Simulation}

The kinetic model developed above was applied to batch reactions conducted by writing the molar balance for each species " $i$ " in the batch reaction system:

$$
\frac{V_{\text {soln }}}{m_{\text {cat }}} \frac{d C_{i}}{d t}=r_{i}
$$

The reaction rates for each species are identical to the right-hand side of Equations (1)-(8) above for the continuous reactor system. The molar balances were integrated over the batch reaction time for each experiment using the Euler's method in Microsoft Excel. The rate constants determined from the continuous reactor data at $230^{\circ} \mathrm{C}$ (Table 3) were used in the rate expressions. Initial concentrations of $\mathrm{EtOH}$ and $\mathrm{IAOH}$ for each experiment are given in Table S4 of Supporting Information. A comparison of experimental and simulated concentrations at the end of each batch experiment for key species in the reaction system is given in Figure 3a-d below. Given that the kinetic model is derived entirely from continuous reactor data, the agreement between experimental and simulated batch results is good. The complete comparison of batch experimental and simulated species concentrations is given in Table S5 of the Supporting Information. 

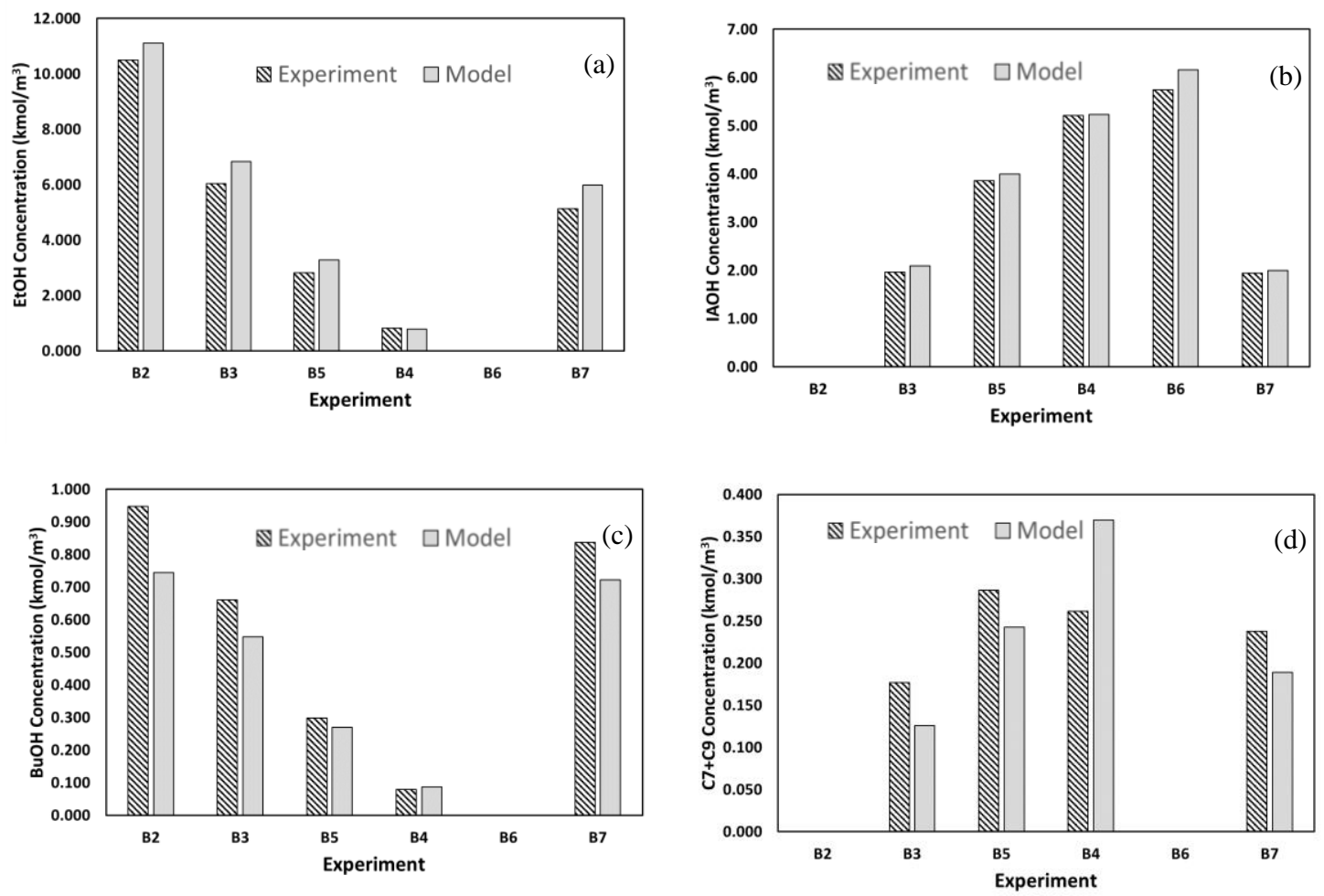

Figure 3. Comparison of batch experimental concentrations at end of reaction with kinetic model simulation. (a)-EtOH; (b)- $\mathrm{IAOH} ;(\mathbf{c})-\mathrm{BuOH}\left(\mathrm{C}_{4}\right) ;(\mathbf{d})-\mathrm{C}_{7}+\mathrm{C}_{9}$ alcohols.

\section{Conclusions}

Guerbet condensation reactions of $\mathrm{EtOH}$ and $\mathrm{IAOH}$ mixtures have been carried out over a lanthanum-promoted nickel on alumina catalyst in both batch and continuous fixed bed flow reactor. The EtOH selectivity toward $\mathrm{C}_{4+}$ alcohols of $94 \%$ at $21 \%$ conversion, and $\mathrm{IAOH}$ selectivity of $87 \%$ to $\mathrm{C}_{7+}$ alcohols (mainly cross-condensation products with EtOH) at $12 \%$ conversion was achieved. A kinetic model has been developed with a Langmuir-Hinshelwood rate expression with product water as the dominant adsorbed species that inhibits reaction, and rate constants have been determined based on the outlet species concentrations from the continuous reactor. The kinetic model developed with continuous reactor data predicts the batch reactor behavior reasonably well.

Supplementary Materials: The following are available online at http://www.mdpi.com/2624-781X/1/2/9/s1, Development of Kinetic Model from "Indirect" Guerbet Reaction Mechanism. Table S1: Rate expressions for Reactions (R1)-(R6) in kinetic model, Evaluation of Intraparticle Mass Transport Resistances. Figure S1: Typical molar compositions of liquid and gas byproducts formed in Guerbet reactions of EtOH and IAOH. Figure S2: Arrhenius plots for rate constants in kinetic model. Table S2: Inlet concentrations of EtOH (E) and IAOH (IA) in continuous reactor. Table S3: Comparison of experimental and simulated outlet concentrations from continuous flow reactor. Table S4: Initial concentrations of EtOH (E) and IAOH (IA) in batch reactions $\left(230^{\circ} \mathrm{C}\right)$. Table S5: Comparison of experimental and simulated species final concentrations for batch reactions at $230{ }^{\circ} \mathrm{C}$.

Author Contributions: Conceptualization, D.J.M. and I.N.; methodology, D.J.M., I.N., and L.P.; validation, D.J.M. and I.N.; formal analysis, D.J.M. and I.N.; investigation, D.J.M. and I.N.; resources, D.J.M. and I.N.; data curation, D.J.M. and I.N.; writing - original draft preparation, D.J.M. and I.N.; writing-review and editing, D.J.M. and I.N.; visualization, D.J.M. and I.N.; supervision, D.J.M.; project administration, D.J.M.; funding acquisition, D.J.M. All authors have read and agreed to the published version of the manuscript.

Funding: This research was funded by U.S. Department of Energy (Award DE-FG36-04GO14216) through a subcontract with the National Corn Growers Association, and by the Michigan State University AgBioResearch Center.

Conflicts of Interest: The authors declare no conflict of interest. 


\section{References}

1. Al Abdallah, Q.; Nixon, B.T.; Fortwendel, J.R. The enzymatic conversion of major algal and cyanobacterial carbohydrates to bioethanol. Front. Energy Res. 2016, 4, 36. [CrossRef]

2. Bergmann, J.C.; Trichez, D.; Sallet, L.P.; de Paula e Silva, F.C.; Almeida, J.R.M. Technological Advancements in $1 \mathrm{G}$ Ethanol Production and Recovery of By-Products Based on the Biorefinery Concept. In Advances in Sugarcane Biorefinery; Chandel, A.K., Luciano Silveira, M.H., Eds.; Elsevier: Amsterdam, The Netherlands, 2018; Chapter 4; pp. 73-95. [CrossRef]

3. Hazelwood, L.A.; Daran, J.-M.; Van Maris, A.J.; Pronk, J.T.; Dickinson, J.R. The Ehrlich pathway for fusel alcohol production: A century of research on Saccharomyces cerevisiae metabolism. Appl. Environ. Microbiol. 2008, 74, 2259-2266. [CrossRef] [PubMed]

4. Tesfaw, A.; Assefa, F. Current trends in bioethanol production by Saccharomyces cerevisiae: Substrate, inhibitor reduction, growth variables, coculture, and immobilization. Int. Sch. Res. Not. 2014, 2014, 532852. [CrossRef] [PubMed]

5. Boumba, V.A.; Ziavrou, K.S.; Vougiouklakis, T. Biochemical pathways generating post-mortem volatile compounds co-detected during forensic ethanol analyses. Forensic Sci. Int. 2008, 174, 133-151. [CrossRef]

6. Tran, T.T.V.; Kongparakul, S.; Karnjanakom, S.; Reubroycharoen, P.; Guan, G.; Chanlek, N.; Samart, C. Selective production of green solvent (isoamyl acetate) from fusel oil using a sulfonic acid-functionalized KIT-6 catalyst. Mol. Catal. 2019, 110724. [CrossRef]

7. Ehrlich, F. Über die Bedingungen der Fuselölbildung und über ihren Zusammenhang mit dem Eiweissaufbau der Hefe. Ber. Dtsch. Chem. Ges. 1907, 40, 1027-1047. [CrossRef]

8. Jackson, R.S. 7-Fermentation. In Wine Science, 3rd ed.; Jackson, R.S., Ed.; Academic Press: San Diego, CA, USA, 2008; pp. 332-417. [CrossRef]

9. Jackson, R.S. Qualitative Wine Assessment. In Wine Tasting, 3rd ed.; Jackson, R.S., Ed.; Academic Press: San Diego, CA, USA, 2017; Chapter 6; pp. 253-291. [CrossRef]

10. Vilanova, M.; Pretorius, I.S.; Henschke, P.A. Influence of Diammonium Phosphate Addition to Fermentation on Wine Biologicals. In Processing and Impact on Active Components in Food; Preedy, V., Ed.; Academic Press: San Diego, CA, USA, 2015; Chapter 58; pp. 483-491. [CrossRef]

11. Marullo, P.; Dubourdieu, D. Yeast selection for wine flavour modulation. In Managing Wine Quality: Oenology and Wine Quality; Elsevier: Amsterdam, The Netherlands, 2010; pp. 293-345. [CrossRef]

12. Koonthongkaew, J.; Toyokawa, Y.; Ohashi, M.; Large, C.R.L.; Dunham, M.J.; Takagi, H. Effect of the Ala234Asp replacement in mitochondrial branched-chain amino acid aminotransferase on the production of BCAAs and fusel alcohols in yeast. Appl. Microbiol. Biotechnol. 2020, 104, 7915-7925. [CrossRef]

13. dos Santos, P.; Meireles, M.A.A.; Martínez, J. Production of isoamyl acetate by enzymatic reactions in batch and packed bed reactors with supercritical $\mathrm{CO}_{2}$. J. Supercrit. Fluids 2017, 127, 71-80. [CrossRef]

14. Branduardi, P.; Porro, D. $n$-butanol: Challenges and solutions for shifting natural metabolic pathways into a viable microbial production. FEMS Microbiol. Lett. 2016, 363, 1-7. [CrossRef]

15. Kang, A.; Lee, T.S. Secondary Metabolism for Isoprenoid-based Biofuels. In Biotechnology for Biofuel Production and Optimization; Eckert, C.A., Trinh, C.T., Eds.; Elsevier: Amsterdam, The Netherlands, 2016; Chapter 2, pp. 35-71. [CrossRef]

16. Bessa, L.C.B.A.; Robustillo, M.D.; Silva, E.C.D.; Tadini, C.C.; Meirelles, A.J.D.A.; Pessôa Filho, P.D.A. Influence of Additives (Isoamyl Laurate or Isoamyl Nonanoate) in the Solid-Liquid Equilibrium of Fatty Acid Ethyl Esters. J. Chem. Eng. Data 2019, 64, 2062-2074. [CrossRef]

17. Safieddin Ardebili, S.M.; Solmaz, H.; İpci, D.; Calam, A.; Mostafaei, M. A review on higher alcohol of fusel oil as a renewable fuel for internal combustion engines: Applications, challenges, and global potential. Fuel 2020, 279, 118516. [CrossRef]

18. Ağbulut, Ü.; Sarıdemir, S.; Karagöz, M. Experimental investigation of fusel oil (isoamyl alcohol) and diesel blends in a CI engine. Fuel 2020, 267, 117042. [CrossRef]

19. Weber, C.; Farwick, A.; Benisch, F.; Brat, D.; Dietz, H.; Subtil, T.; Boles, E. Trends and challenges in the microbial production of lignocellulosic bioalcohol fuels. Appl. Microbiol. Biotechnol. 2010, 87, 1303-1315. [CrossRef] [PubMed] 
20. Mohsenzadeh, A.; Zamani, A.; Taherzadeh, M.J. Bioethylene Production from Ethanol: A Review and Techno-economical Evaluation. ChemBioEng Rev. 2017, 4, 75-91. [CrossRef]

21. Xiang, N.; Xu, P.; Ran, N.; Ye, T. Production of acetic acid from ethanol over CuCr catalysts via dehydrogenation-(aldehyde-water shift) reaction. RSC Adv. 2017, 7, 38586-38593. [CrossRef]

22. Nezam, I.; Peereboom, L.; Miller, D.J. Continuous condensed-phase ethanol conversion to higher alcohols: Experimental results and techno-economic analysis. J. Clean. Prod. 2019, 209, 1365-1375. [CrossRef]

23. Gabriëls, D.; Hernández, W.Y.; Sels, B.; Van Der Voort, P.; Verberckmoes, A. Review of catalytic systems and thermodynamics for the Guerbet condensation reaction and challenges for biomass valorization. Catal. Sci. Technol. 2015, 5, 3876-3902. [CrossRef]

24. Wu, X.; Fang, G.; Tong, Y.; Jiang, D.; Liang, Z.; Leng, W.; Liu, L.; Tu, P.; Wang, H.; Ni, J.; et al. Catalytic Upgrading of Ethanol to n-Butanol: Progress in Catalyst Development. ChemSusChem 2018, 11, 71-85. [CrossRef]

25. Cheng, F.; Guo, H.; Cui, J.; Hou, B.; Xi, H.; Jia, L.; Li, D. Coupling of methanol and ethanol over CuMgAlO catalysts: The roles of copper species and alkalinity. React. Kinet. Mech. Catal. 2019, 126, 119-136. [CrossRef]

26. Benito, P.; Vaccari, A.; Antonetti, C.; Licursi, D.; Schiarioli, N.; Rodriguez-Castellón, E.; Raspolli Galletti, A.M. Tunable copper-hydrotalcite derived mixed oxides for sustainable ethanol condensation to $n$-butanol in liquid phase. J. Clean. Prod. 2019, 209, 1614-1623. [CrossRef]

27. Li, S.; Zhu, X.; An, H.; Zhao, X.; Wang, Y. Ethanol Guerbet Condensation to $n$-Butanol or $\mathrm{C}_{4}-\mathrm{C}_{8}$ Alcohols over $\mathrm{Ni} / \mathrm{TiO}_{2}$ Catalyst. ChemistrySelect 2020, 5, 8669-8673. [CrossRef]

28. Han, X.; Li, S.; Zhu, X.; An, H.; Zhao, X.; Wang, Y. Influence of noble metals on the catalytic performance of $\mathrm{Ni} / \mathrm{TiO}_{2}$ for Ethanol Guerbet condensation. React. Kinet. Mech. Catal. 2020. [CrossRef]

29. Matsu-ura, T.; Sakaguchi, S.; Obora, Y.; Ishii, Y. Guerbet Reaction of Primary Alcohols Leading to $\beta$-Alkylated Dimer Alcohols Catalyzed by Iridium Complexes. J. Org. Chem. 2006, 71, 8306-8308. [CrossRef] [PubMed]

30. Busch, S.; Fleute-Schlachter, I.; Mack, S.; Mahnke, E.U.; Wick, A. Biocide Compositions Comprising Alkoxylation Products of Isoamyl Alcohol Derivatives. U.S. Patent Application No. 20130252982, 22 November 2016.

31. Nezam, I.; Zak, J.; Miller, D.J. Condensed-Phase Ethanol Conversion to Higher Alcohols over Bimetallic Catalysts. Ind. Eng. Chem. Res. 2020, 59, 13906-13915. [CrossRef]

32. Jordison, T.L.; Lira, C.T.; Miller, D.J. Condensed-Phase Ethanol Conversion to Higher Alcohols. Ind. Eng. Chem. Res. 2015, 54, 10991-11000. [CrossRef]

33. Jordison, T.L.; Peereboom, L.; Miller, D.J. Impact of Water on Condensed Phase Ethanol Guerbet Reactions. Ind. Eng. Chem. Res. 2016, 55, 6579-6585. [CrossRef]

34. Nezam, I.; Peereboom, L.; Miller, D.J. Enhanced Acrylate Production from 2-Acetoxypropanoic Acid Esters. Org. Proc. Res. Dev. 2017, 21, 715-719. [CrossRef]

35. Vlasenko, N.V.; Kyriienko, P.I.; Valihura, K.V.; Kosmambetova, G.R.; Soloviev, S.O.; Strizhak, P.E. Yttria-Stabilized Zirconia as a High-Performance Catalyst for Ethanol to n-Butanol Guerbet Coupling. ACS Omega 2019, 21469-21476. [CrossRef]

36. Xi, X.-Y.; Sun, Z.-H.; Cao, H.-T.; Pei, Y.-T.; ten Brink, G.H.; Deuss, P.J.; Barta, K.; Heeres, H.J. Catalyst Performance Studies on the Guerbet Reaction in a Continuous Flow Reactor Using Mono-and Bi-Metallic Cu-Ni Porous Metal Oxides. Catalysts 2020, 10, 996. [CrossRef]

37. Neumann, C.N.; Rozeveld, S.J.; Yu, M.; Rieth, A.J.; Dincă, M. Metal-Organic Framework-Derived Guerbet Catalyst Effectively Differentiates between Ethanol and Butanol. J. Am. Chem. Soc. 2019, 141, 17477-17481. [CrossRef]

38. Larina, O.V.; Valihura, K.V.; Kyriienko, P.I.; Vlasenko, N.V.; Balakin, D.Y.; Khalakhan, I.; Čendak, T.; Soloviev, S.O.; Orlyk, S.M. Successive vapour phase Guerbet condensation of ethanol and 1-butanol over Mg-Al oxide catalysts in a flow reactor. Appl. Catal. A Gen. 2019, 588, 117265. [CrossRef]

39. Zakumbaeva, G.D.; Omashev, K.G.; Khan, C. Influence of water on the heat of hydrogen adsorption on nickel. React. Kinet. Catal. Lett. 1977, 6, 363-369. [CrossRef]

40. Renouprez, A.J.; Fouilloux, P.; Candy, J.P.; Tomkinson, J. Chemisorption of water on nickel surfaces. Surf. Sci. 1979, 83, 285-295. [CrossRef] 
41. Rahman, M.M.; Davidson, S.D.; Sun, J.; Wang, Y. Effect of Water on Ethanol Conversion over ZnO. Top. Catal. 2016, 59, 37-45. [CrossRef]

42. Cabello González, G.M.; Concepción, P.; Villanueva Perales, A.L.; Martínez, A.; Campoy, M.; Vidal-Barrero, F. Ethanol conversion into 1,3-butadiene over a mixed Hf-Zn catalyst: Effect of reaction conditions and water content in ethanol. Fuel Process. Technol. 2019, 193, 263-272. [CrossRef]

Publisher's Note: MDPI stays neutral with regard to jurisdictional claims in published maps and institutional affiliations.

(C) 2020 by the authors. Licensee MDPI, Basel, Switzerland. This article is an open access article distributed under the terms and conditions of the Creative Commons Attribution (CC BY) license (http://creativecommons.org/licenses/by/4.0/). 